\title{
Digestibility and rumen fermentation of a high forage diet pre-treated with a mixture of cellulase and xylanase enzymes
}

\author{
K. Selzer ${ }^{1}$, A. Hassen ${ }^{1 \#}$, A.M. Akanmu ${ }^{1}$ \& A.Z.M. Salem ${ }^{2}$ \\ ${ }^{1}$ Department of Animal Sciences, University of Pretoria, Pretoria, South Africa \\ ${ }^{2}$ Depto. de Nutrición Animal, Facultad de Medicina Veterinaria y Zootecnia, Universidad Autónoma del, Estado \\ de México, Toluca, Edo de México, México
}

(Received 20 June 2019; Accepted 25 November 2020; Published 19 June 2021)

\begin{abstract}
Copyright resides with the authors in terms of the Creative Commons Attribution 4.0 South African Licence.
See: http://creativecommons.org/licenses/by/4.0/za

Condition of use: The user may copy, distribute, transmit and adapt the work, but must recognise the authors and the South African Journal of Animal Science.
\end{abstract}

\begin{abstract}
Forages play an important role in ruminant animal production worldwide. Unlocking the nutritional potential of poor-quality tropical forages with fibrolytic enzymes would improve forage digestibility and utilization. Using in vitro and in vivo methods this study investigated the effect of pre-treating Smutsfinger hay for 24 hours with a mixture of fibrolytic enzyme (100\% cellulase; $75 \%$ cellulase: $25 \%$ xylanase; $50 \%$ cellulase: $50 \%$ xylanase; $25 \%$ cellulase: $75 \%$ xylanase; $100 \%$ xylanase and a control with no enzyme) on ruminal fermentation and digestibility of nutrients by sheep. For in vitro fermentation, dry matter, neutral detergent fibre (NDF) degradability and volatile fatty acids (VFA) were determined with standard procedures. The same treatments were used for an in vivo digestibility trial using Merino sheep in a $6 \times 6$ Latin square design. Feed intake and total tract digestibility were recorded. Rumen fluid samples were collected daily, preserved, and analysed for VFA. The addition of $100 \%$ cellulase enzyme to Smutsfinger hay in vitro increased $(P<0.05)$ NDF degradability and gas production compared with the control and inclusion of $100 \%$ xylanase enzyme. Both $100 \%$ cellulase and xylanase enzymes significantly reduced in vitro end time fermentation $\mathrm{pH}$. A 50:50 mixture of cellulase and xylanase plus enzyme in vivo, increased acetate, total VFA concentration, and higher NDF and ADF digestibility of the test feed compared with the control. Inclusion of a $50-75 \%$ mixture of cellulase and $50-25 \%$ xylanase enzymes treatment led to higher gas production and butyrate concentration, decreased ruminal $\mathrm{pH}$ and improved nutrient digestibility.
\end{abstract}

Keywords: fibrolytic enzymes, ruminants, sheep, volatile fatty acids

\#Corresponding author: Abubeker.hassen@up.ac.za

\section{Introduction}

Forages comprise the biggest part of feeding cost. During the dry season, crop residues and poor quality grasses from rangelands are basal feeds for ruminants in developing countries with tropical climates. Tropical pastures and crop residue are often of variable quality, and are of low nutritional value at maturity because the high rate of lignification (Meissner, 1997) leads to poorer degradation and lower feed utilization efficiency (Krueger et al., 2008) and result in increased cost of production owing to the elongated period for animals to reach their growth potential.

Ruminants, however, have adapted to feed of low quality for growth and production owing to the diverse microbial community in their rumen, but production efficiency is not optimal. Less than $50 \%$ of the fibre fraction is readily digested and utilized by the animal (Hatfield et al., 1999). This inefficiency can result in an increase in the quantity of feed needed to maintain the required levels of animal performance. Thus, any improvement in the degradation of the forage cell wall could be of great benefit. Hence this presents a logical area of research for the improvement of forage utilization.

As additives to ruminant nutrition, exogenous fibrolytic enzymes are of growing interest as a way of improving digestibility of fibrous feeds. For instance, cellulase, xylanase and pectinase are used in ruminant feed biotechnology to improve feed utilization, to affect the production of milk and meat and to improve the digestibility of certain feed components. They have been studied extensively in the last couple of decades as a viable means of improving the digestibility of forages typically used in ruminant nutrition. Enzymes such as cellulase and xylanase, which degrade the cell wall, could hydrolyse forage fibre (Feng et al., 1996). Thus, 
supplementation with fibrolytic enzymes may have a positive role in improving the digestibility (Bala et al., 2009; Feng et al., 1996; Geraldo et al., 2008) of the roughage proportion, thereby decreasing the retention time in the rumen and perhaps increasing feed intake. Most research on fibrolytic enzyme additives in ruminants has been conducted on beef and dairy cattle. Research on its effects on small ruminants such as sheep would be beneficial and was the focus of this study. The current in vivo and in vitro study had the objective of establishing the effects of various proportions of cellulase and xylanase enzyme mixtures on the gas production, and dry matter, organic matter, neutral detergent fibre and acid detergent fibre digestibility in sheep fed a high roughage total mixed ration, and the effect of the supplementation on VFA production in sheep.

\section{Material and methods}

This study was completed at the experimental farm of the University of Pretoria, with ethical clearance from the Animal Ethics Committee (project number EC113-13). Dry matter and ash contents of the Smutsfinger hay and TMR were determined according to methods 934.01 and 942.05, respectively (AOAC, 2019). Methods 12 and 13 of ANKOM Technology (Macedon, New York, USA) were used to determine ADF and NDF. The nitrogen $(\mathrm{N})$ concentration of the TMR was determined with TruMac N (Leco Corp. St. Joseph, Michigan, USA) following the manufacturer's recommended procedure for implementing method 968.06 (AOAC, 2019). Crude protein concentration was calculated by multiplying the $\mathrm{N}$ percentage by a factor of 6.25. Tables 1 and 2 show the nutrient composition of Smutsfinger hay used in the in vitro trial and of the TMR, which was formulated at maintenance level for the in vivo study.

Table 1 Nutrient composition of Smutsfinger hay $(\mathrm{g} / \mathrm{kg})$

\begin{tabular}{lcc}
\hline Chemical components & As is basis & Dry matter basis \\
\hline Dry matter & 881.0 & 1000 \\
Organic matter & 891.6 & 876.9 \\
Ash & 108.4 & 123.1 \\
Crude protein & 53.9 & 61.2 \\
Neutral detergent fibre & 651.8 & 739.8 \\
Acid detergent fibre & 417.4 & 473.8 \\
\hline
\end{tabular}

Table 2 Ingredient and nutrient composition of total mixed ration to be fed to mature sheep

\begin{tabular}{lc}
\hline Ingredients & \% composition \\
\hline Yellow maize & 33.9 \\
Wheat middling & 6.2 \\
Molasses & 8.0 \\
Limestone powder - hand add & 0.47 \\
Salt & 1.22 \\
Urea & 0.08 \\
Vitamin/mineral supplement & 0.15 \\
Chemical components & $\mathrm{DM}(\mathrm{g} / \mathrm{kg})$ \\
Organic matter & 906.9 \\
Ash & 93.1 \\
Crude protein & 77.2 \\
Neutral detergent fibre & 402.2 \\
Acid detergent fibre & 233.7 \\
\hline
\end{tabular}


For both experiments, six treatments were tested, including the control, which consisted of various proportions of the exogenous fibrolytic enzymes cellulase plus and xylanase plus. The cellulase plus and xylanase plus enzymes were obtained from Dyadic International Inc. (Jupiter, Florida, USA) as concentrated liquids of acid cellulase (E.C. 3.2.1.4) and acid-neutral endo-1, 4- $\beta$-D-xylanase (E.C. 3.2.1.8), respectively. They were produced by the fermentation of non-genetically modified Trichoderma longibrachiatum (formerly Trichoderma reesei). The level of addition was based on the outcome of a previous study (Gemeda et al., 2014). About $20 \mathrm{ul}$ of each enzyme treatment was added to $100 \mathrm{ml}$ distilled water. Smutsfinger hay was dried at $55{ }^{\circ} \mathrm{C}$ for 24 hours and milled through a $1-\mathrm{mm}$ screen. Approximately $0.5 \mathrm{~g}$ of the milled sample was weighed into incubation vials. All enzyme treatments were applied 24 hours prior to incubation to allow for the enzyme-substrate interaction (Beauchemin et al., 2003). Approximately $1 \mathrm{~mL}$ of the appropriate enzyme treatment was pipetted directly onto the substrate already in the incubation vials 24 hours before the start of in vitro incubation and left at room temperature. These treatments that were applied to the Smutsfinger hay in both the in vitro and in vivo experiments:

T1: TMR plus hay treated with $0.4 \mathrm{ml} / \mathrm{kg}$ cellulase plus (100\%) and $0.0 \mathrm{ml} / \mathrm{kg}$ xylanase plus $(0 \%)$

T2: TMR plus hay treated with $0.3 \mathrm{ml} / \mathrm{kg}$ cellulase plus $(75 \%)$ and $0.1 \mathrm{ml} / \mathrm{kg}$ xylanase plus $(25 \%)$

T3: TMR plus hay treated with $0.2 \mathrm{ml} / \mathrm{kg}$ cellulase plus $(50 \%)$ and $0.2 \mathrm{ml} / \mathrm{kg}$ xylanase plus $(50 \%)$

T4: TMR plus hay treated with $0.1 \mathrm{ml} / \mathrm{kg}$ cellulase plus (25\%) and $0.3 \mathrm{ml} / \mathrm{kg}$ xylanase plus $(75 \%)$

T5: TMR plus hay treated with $0.0 \mathrm{ml} / \mathrm{kg}$ cellulase plus $(0 \%)$ and $0.4 / \mathrm{kg}$ xylanase plus $(100 \%)$

T6: Control without enzyme

Rumen fluid was collected from three Merino sheep at the small stock section, University of Pretoria Experimental Farm. The animals were fed lucerne ad libitum as basal diet with two feedings a day to ensure constant availability of fresh feed and consistency of the rumen fluid. Rumen liquor was collected from at least two animals and squeezed through two layers of cheesecloth. At the laboratory, the rumen fluid was further strained through a single layer of cheesecloth to ensure that any large feed particles were removed before it was transferred to a large glass beaker that had been pre-warmed in a water bath at $39{ }^{\circ} \mathrm{C}$ and purged continuously with $\mathrm{CO}_{2}$.

The incubation media was prepared according to Menke and Steingass (1988). A few hours before in vitro incubation, $2.5 \mathrm{~g}$ tryptone was dissolved completely in $500 \mathrm{~mL}$ water. Then, $0.125 \mathrm{~mL}$ micro-mineral solution, $250 \mathrm{~mL}$ buffer solution, $250 \mathrm{~mL}$ macro-mineral solution, and $1.25 \mathrm{~mL} 0.1 \%$ resazurin solution were added. The container with the media was then placed in a water bath at $39{ }^{\circ} \mathrm{C}$ and purged continuously with $\mathrm{CO}_{2}$ for 45 minutes. To reduce oxygen, approximately $0.313 \mathrm{~g} \mathrm{~L}$-cysteine hydrochloride and $0.313 \mathrm{~g}$ sodium sulphide was added and purged with $\mathrm{CO}_{2}$ continuously for another 15 minutes or until the solution turned from grey to clear. The medium was then kept in the water bath with continuous $\mathrm{CO}_{2}$ bubble. One part of rumen fluid was added to four parts buffer solution. The vials containing the enzyme-feed complex were placed in the incubation oven at $39{ }^{\circ} \mathrm{C}$ to warm them and prevent cold shock to the rumen fluid microorganisms. Approximately $42 \mathrm{~mL}$ ( $84 \mathrm{~mL} / \mathrm{g}$ substrate) of rumen fluid plus medium was then added to the enzyme-feed complex under a stream of $\mathrm{CO}_{2}$ to each vial and the vials were closed immediately with rubber stoppers and crimp sealed. The bottles were returned to the oven and set to rotate at $120 \mathrm{rpm}$. When all the bottles had been filled, a needle was inserted through the rubber stopper of each vial for about five seconds to release built-up gas and to create the starting point for the vials. Three independent runs were performed with four replications per treatment in each run.

A semi-automated system was used for the gas pressure readings. It consisted of a digital pressure gauge with a Luer lock adapter and disposable needle. Gas pressure and methane concentration were measured and cumulated at 2, 4, 8, 12, 24, and 48 hrs to avoid pressure build up that exceeded 7 psi, which could be re-absorbed into the liquid phase. Digital gas pressure readings were converted to gas volumes produced in $\mathrm{mL}$ (Akanmu \& Hassen, 2018). Incubation was terminated after $48 \mathrm{hr}$ by placing the incubation vials on ice to stop fermentation. The vials were opened as soon as possible to sample the supernatant aliquots for VFA. The $\mathrm{pH}$ of the fluid was then measured using a $\mathrm{pH}$ meter. To determine VFAs, $4 \mathrm{~mL} 25 \%$ phosphoric acid was added to $20 \mathrm{~mL}$ filtered rumen sample. This was mixed and stored at $-20{ }^{\circ} \mathrm{C}$ until required. The samples were analysed for VFAs by defrosting and centrifuged at $4500 \mathrm{rpm}$ for 20 minutes before being filtered through Cameo $30(0.45 \mu \mathrm{m})$ filters (Webb, 1994). In vitro dry matter digestibility and fibre analysis were carried out on the fermented residue following standard procedures. Dry matter of Smutsfinger hay was also determined. All the results were converted to a $100 \%$ DM basis and the degradability of nutrients calculated as follows.

$\%$ Dry matter degradability $=(\mathrm{g} \underline{\mathrm{DM}}$ in $0.5 \mathrm{~g}$ Smutsfinger hay $-\mathrm{g}$ DM in residue after incubation $) \times 100$ $\mathrm{g}$ DM in $0.5 \mathrm{~g}$ Smutsfinger 
The in vivo experiment was a $6 \times 6$ Latin square design. Six sheep were allocated to one of the six treatments at six periods. The first adaptation and experimental period consisted of 24 days, of which 14 days were for adaptation and the other 10 days for data collection on feed intake, faecal output, rumen digestibility and rumen sampling. The sheep were fed a TMR formulated for maintenance level throughout the experimental period. Feeding took place ad libitum twice a day at $06 \mathrm{~h} 00$ and $16 \mathrm{~h} 00$, and fresh clean water was made available at all times. Amounts of feed offered and refused were recorded daily and the bodyweights were recorded at the beginning of each experimental period and at the end of each cycle. Smutsfinger hay was pre-incubated for $24 \mathrm{hrs}$ with the prepared enzyme solution separately for each treatment. Initially, animals were fed untreated TMR for 14 days before the start of adaptation. On the morning of feeding the pre-treated Smutsfinger hay was mixed with the appropriate amount of concentrate to form the TMR. The animals were housed in single metabolic cages with one sheep assigned to each treatment. The sheep were fed ad libitum and were fitted with a faecal collection bag during the last three days of adaptation to allow them to adapt to the faecal bags before the 10 days of data collection, during which the faecal bags stayed on. The amounts of feed offered and refusals were weighed, recorded and sub-sampled daily, and faecal output was weighed, recorded, sub-sampled and frozen each day. The subsampled feed and faeces were later dried and analysed to determine DM, ash, OM, CP, NDF, and ADF. Rumen liquor had been collected twice a day for four consecutive days by extending the collection time by three hours in the subsequent days. Rumen content was squeezed through two layers of cheesecloth into containers and a small amount of inoculum was added. The rumen fluid was prepared for the gas chromatographic method to determine VFAs as described. The data were analysed using the general linear model procedure of SAS 9.4 (SAS Institute, Inc., Cary, North Carolina). Means were compared using Duncan's test when the treatment effect was significant.

\section{Result and Discussion}

The cumulative gas reading after $48 \mathrm{hr}$ incubation differed $(P<0.05)$ among treatments. Higher $(P$ $<0.05)$ TGP values were observed for T1 and T2 than for the control and T3 - T5. The corresponding increase in gas production associated with the addition of cellulase was similar to the findings of Gemeda et al. (2014). In another study, Kung et al. (2002) found higher gas production from forages treated with enzymes than that of untreated forage. Cellulases are used widely in any process that involves processing of plant-based materials. The characteristic enzymatic endo-hydrolysis of $\beta-1,4 \mathrm{D}$-glycosidic bonds in cellulose and in $\beta$--D-glucans (Fernandes, 2008) makes it an important enzyme in animal agriculture and could be responsible for the higher TGP witnessed in this study. Higher inclusion of cellulose led to more TGP. The results of TGP in $\mathrm{mL} / \mathrm{g}$ DM are shown in Table 3 with the fermentation parameters and feed degradability.

The results showed no difference $(P>0.05)$ in DM degradability, although higher degradability values were obtained for the groups treated with enzyme. However, percentage NDF degradability differed $(P$ $<0.05)$. Compared with the control, T1 and T2 had higher NDF degradability, whereas the other treatments were the same as control statistically. These findings correlate with those of Alvarez et al. (2009), Bala et al. (2009) and Lewis et al. (1996) as these authors reported increased nutrient degradability for feeds treated with cellulase and xylanase enzymes compared with control. According to these results, cellulase and xylanase can improve fibre degradation, and the best enzyme treatment for increased degradation would be a $100 \%$ cellulase treatment. The 24 -hour pre-incubation of feed sample with enzymes in the present study might have produced an improvement in the attachment of micro-organisms to the plant cell wall components (Nsereko et al., 2000; Wang et al., 2001), leading to increased colonization and alteration in the fibre structure because of enzyme effects (Sutton et al., 2003; Elwakeel et al., 2007; Giraldo et al., 2008). Dry matter and NDF degradability after $48 \mathrm{hr}$ incubation of Smutsfinger hay with various enzyme mixtures are presented in Table 3. 
Table 3 In vitro gas and methane production and fermentation characteristics of Smutsfinger hay treated with cellulase and xylanase enzymes

\begin{tabular}{lccccccc}
\hline Characteristics & T1 & T2 & T3 & T4 & T5 & T6 & SE \\
\hline Total gas production, ml/g DM & $179.8^{\mathrm{a}}$ & $172.8^{\mathrm{a}}$ & $170.4^{\mathrm{ab}}$ & $153.1^{\mathrm{c}}$ & $157.4^{\mathrm{bc}}$ & $155.2^{\mathrm{bc}}$ & 19.51 \\
Methane production, $\mathrm{ml} / \mathrm{g} \mathrm{DM}$ & $69.3^{\mathrm{a}}$ & $67.4^{\mathrm{ab}}$ & $63.3^{\mathrm{ab}}$ & $60.3^{\mathrm{ab}}$ & $59.7^{\mathrm{ab}}$ & $57.8^{\mathrm{b}}$ & 10.17 \\
Dry matter digestibility, \% & 33.4 & 32.5 & 30.6 & $31.8^{\mathrm{bc}}$ & 29.9 & 29.6 & 4.92 \\
$\mathrm{NDF}$ degradability, \% & $36.0^{\mathrm{a}}$ & $33.7^{\mathrm{ab}}$ & $31.7^{\mathrm{bc}}$ & $30.4^{\mathrm{bc}}$ & $30.0^{\mathrm{c}}$ & $28.2^{\mathrm{bc}}$ & 4.46 \\
$\mathrm{pH}$ & $6.5^{\mathrm{c}}$ & $6.5^{\mathrm{c}}$ & $6.7^{\mathrm{a}}$ & $6.6^{\mathrm{b}}$ & $6.5^{\mathrm{c}}$ & $6.7^{\mathrm{ab}}$ & 0.00 \\
Acetate, $\mathrm{mM} / \mathrm{L}$ & 43.3 & 42.7 & 42.1 & 41.1 & 43.0 & 41.9 & 2.45 \\
Propionate, $\mathrm{mM} / \mathrm{L}$ & 14.8 & 14.6 & 14.5 & 14.4 & 14.8 & 14.4 & 0.23 \\
Iso-Butyrate, $\mathrm{mM} / \mathrm{L}$ & 1.4 & 1.38 & 1.34 & 1.34 & 1.4 & 1.35 & 0.00 \\
Butyrate, $\mathrm{mM} / \mathrm{L}$ & $4.9^{\mathrm{a}}$ & $4.7^{\mathrm{ab}}$ & $4.7^{\mathrm{ab}}$ & $4.6^{\mathrm{ab}}$ & $4.8^{\mathrm{a}}$ & $4.6^{\mathrm{b}}$ & 0.03 \\
Valerate, $\mathrm{mM} / \mathrm{L}$ & 1.9 & 1.9 & 1.8 & 1.9 & 1.9 & 1.8 & 0.01 \\
Total volatile fatty acids, $\mathrm{mM} / 9^{\prime}$ & 66.3 & 65.2 & 64.4 & 63.4 & 65.9 & 64 & 5.01 \\
Acetate to propionate ratio & 2.9 & 2.9 & 2.9 & 2.9 & 2.9 & 2.9 & 0.00 \\
\hline
\end{tabular}

${ }^{a, b, c}$ Within a row, means with a similar superscript were not detected as being different with probability $P=0.05$

NDF: neutral detergent fibre, T1: TMR plus hay treated with $0.4 \mathrm{ml} / \mathrm{kg}$ cellulase plus and $0.0 \mathrm{ml} / \mathrm{kg}$ xylanase plus, T2: TMR plus hay treated with $0.3 \mathrm{ml} / \mathrm{kg}$ cellulase plus and $0.1 \mathrm{ml} / \mathrm{kg}$ xylanase plus, T3: TMR plus hay treated with $0.2 \mathrm{ml} / \mathrm{kg}$ cellulase plus and $0.2 \mathrm{ml} / \mathrm{kg}$ xylanase plus, T4: TMR plus hay treated with $0.1 \mathrm{ml} / \mathrm{kg}$ cellulase plus and $0.3 \mathrm{ml} / \mathrm{kg}$ xylanase plus, T5: TMR plus hay treated with $0.0 \mathrm{ml} / \mathrm{kg}$ cellulase plus, and $0.4 / \mathrm{kg}$ xylanase plus, T6: control without enzyme addition

Volatile fatty acid production and end fermentation $\mathrm{pH}$ showed no difference $(P>0.05)$ across treatments, except for butyrate. T1 and T5 had higher $(P<0.05)$ butyric acid production compared with the control and other treatments. This agrees with Krueger et al. (2008), who reported an increase in butyrate concentrations with the addition of cellulase and xylanase enzymes on Bahia grass hay. In contrast with the findings of this study, Gemeda et al. (2014) recorded generally higher acetate and total VFA concentration for the samples treated with cellulase and xylanase compared with the control. Kung et al. (2002) recorded that VFA production did not vary among treatments. The results of this study agree with those of Yang et al. (2002), who found that the addition of an enzyme did not affect acetate and total VFA concentrations, but showed increased molar proportions, with T1 and T5 in this study being the most effective compared with control. The reason for the high butyrate concentration and a tendency towards higher acetate and total VFA proportions in T1 and T5 could be an increase in the reactivity of the enzyme after the 24-hour incubation, which could have caused enhanced colonization and digestion of slowly degradable fibre fraction by ruminal micro-organisms. A reduced $\mathrm{pH}$ value recorded for $\mathrm{T} 1$ and $\mathrm{T} 5$ could have influenced the rumen fermentation process. There was no difference $(P>0.05)$ between the $\mathrm{pH}$ values of the control and those of T3 and T4 xylanase treatment. However, there was a $(P<0.05)$ difference between the other treatments and the control, indicating a reduction in the end fermentation $\mathrm{pH}$ with higher cellulase inclusion. The findings of this study agree with those of Lewis et al. (1996), who reported decreased ruminal pH in steers fed grass forage treated with exogenous enzymes, with T1 and T5 being the most effective compared with control.

There was a difference $(P<0.05)$ between the treatments in terms of DM intake per unit metabolic body weight where the addition of cellulose and xylanase increased DM intake compared with T1. The results of this study agree with those of Chen et al. (1992), Fredeen et al. (1993), and Bala et al. (2009), all of whom found an increase in DM intake with the addition of cellulase and xylanase enzyme mixtures. In contrast, Lewis et al. (1996) and Rode et al. (1999) showed that exogenous fibrolytic enzymes fed directly to the animal or added to the feed did not affect the DM intake of cattle. The lack of response in intake improvement may be because enzymes were being fed directly into the rumen and were not pre-treated for 24 hours before feeding, as in this experiment, which gave the enzymes ample time to pre-act on the feed. Table 4 shows the DM intake ( $/$ /head/kg $\mathrm{W}^{0.75}$ ) and nutrient digestibility.

However, other studies found different responses to the addition of enzymes. Rodriguez et al. (2002) reported that the addition of cellulose and xylanase increased DM intake, whereas Feng et al. (1996) reported that DM intake was increased by fibrolytic enzymes when added to dry forages, but not when fresh forages were used. This study shows that T3 improved DM intake most. This finding agreed with those of 
Bala et al. (2009), in which the addition of a $50 \%$ mixture of cellulase and xylanase enzymes prior to feeding was more effective in small ruminants than feeding these enzymes separately or not at all. The gut fill capacity, in relation to forage characteristics, could be considered a main factor of regulation of voluntary intake (Decruyenaere et al., 2009). Intake appeared to be limited by the maximal volume that the digestive tract can reach (Allison, 1985; Allen, 1996). If the transit rate of digesta could be increased when the quality of forage was poor, intake could increase (Johnson \& Combs, 1992). The increase in intake thus appeared to be because of increased total tract digestibility of the fibre proportion of the feed, allowing the animal to empty its gut better, making more space for additional intake.

Table 4 Intake and nutrient digestibility of rams fed diets containing cellulase and xylanase enzymes

\begin{tabular}{llllllll}
\hline Variable & T1 & T2 & T3 & T4 & T5 & T6 & SE \\
\hline Intake, g DM/head/kg W ${ }^{0.75}$ & $47.6^{\mathrm{d}}$ & $62.3^{\mathrm{bc}}$ & $78.2^{\mathrm{a}}$ & $58.4^{\mathrm{bc}}$ & $64.7^{\mathrm{b}}$ & $60.9^{\mathrm{bc}}$ & 13.2 \\
DM digestibility, g DM/head/d & 610 & 630 & 680 & 600 & 660 & 600 & 60.1 \\
Organic matter digestibility, g DM/head/d & 620 & 640 & 690 & 610 & 670 & 620 & 51.1 \\
Crude protein digestibility, g DM/head/d & 460 & 510 & 580 & 480 & 540 & 450 & 11.4 \\
NDF digestibility, g DM/head/d & $490^{\mathrm{ab}}$ & $490^{\mathrm{ab}}$ & $580^{\mathrm{a}}$ & $430^{\mathrm{b}}$ & $520^{\mathrm{ab}}$ & $430^{\mathrm{b}}$ & 10.2 \\
ADF digestibility, g DM/head/d & $400^{\mathrm{ab}}$ & $440^{\mathrm{ab}}$ & $520^{\mathrm{a}}$ & $350^{\mathrm{ab}}$ & $430^{\mathrm{ab}}$ & $240^{\mathrm{b}}$ & 36.3
\end{tabular}

${ }^{\mathrm{a}, \mathrm{b}, \mathrm{c}}$ Within a row, means with a similar superscript were not detected as being different with probability $P=0.05$

DM: dry matter, NDF: neutral detergent fibre, ADF: acid detergent fibre, T1: TMR plus hay treated with $0.4 \mathrm{ml} / \mathrm{kg}$ cellulase plus and $0.0 \mathrm{ml} / \mathrm{kg}$ xylanase plus, T2: TMR plus hay treated with $0.3 \mathrm{ml} / \mathrm{kg}$ cellulase plus and $0.1 \mathrm{ml} / \mathrm{kg}$ xylanase plus, T3: TMR plus hay treated with $0.2 \mathrm{ml} / \mathrm{kg}$ cellulase plus and $0.2 \mathrm{ml} / \mathrm{kg}$ xylanase plus, T4: TMR plus hay treated with $0.1 \mathrm{ml} / \mathrm{kg}$ cellulase plus and $0.3 \mathrm{ml} / \mathrm{kg}$ xylanase plus, T5: TMR plus hay treated with $0.0 \mathrm{ml} / \mathrm{kg}$ cellulase plus, and $0.4 / \mathrm{kg}$ xylanase plus, T6: control without enzyme addition

The total tract digestibility of various nutrients in sheep fed fibrolytic enzymes did not significantly affect the digestibility of the DM, OM and CP components, though there was a tendency towards higher values in the treatments that included enzyme than the control. This agrees with the findings of Burroughs et al. (1960) and Theurer et al. (1963), who reported no effect of fibrolytic enzymes on the digestibility of DM, $\mathrm{OM}$ and CP. In this study, however, the digestibility of the fibre component (NDF and ADF) increased for the $50 \%$ cellulase and xylanase mixture compared with control $(P<0.05)$. These findings agree with the reports of other researchers who found an increase in digestibility of various quality forages (Bala et al., 2009; Feng et al., 1996; Geraldo et al., 2008). The mechanism responsible for this increase in digestibility might be the synergistic action of the cellulase and xylanase enzymes, which is believed to come from the ability of xylanase to expose the cellulose microfibril core by removing the hemicellulose or the hemicellulosic side chains (Selig et al., 2008).

Feeds that are high in rapidly fermentable carbohydrates lead to increased microbial populations that favour production of more propionate and butyrate than acetate (Moran, 2005). Higher acetate production comes mainly from slowly fermentable forages. Table 5 shows the VFA production in $\mathrm{mM} / \mathrm{L}$. There was a difference $(P<0.05)$ between the control and the 50:50 cellulase and xylanase mixture in acetate and total VFA production. These results agree with the in vitro results reported in Table 3 and those of Gemeda et al. (2014), who recorded that acetate and total VFA concentration tended to be higher for the samples treated with enzyme compared with the control. The mechanism responsible for the increase in acetate production might be the synergistic action of the cellulase and xylanase enzymes in the $50 \%$ mixture treatment, which resulted in greater NDF and ADF digestibility than the control treatment. 
Table 5 Volatile fatty acids (mM/L) of rams fed diets containing cellulase and xylanase enzymes

\begin{tabular}{lrrrrrrr}
\hline Volatile fatty acid & T1 & \multicolumn{1}{c}{ T2 } & T3 & T4 & T5 & T6 & SE \\
\hline Acetate & $36.9 \mathrm{~b}$ & $36.1 \mathrm{~b}$ & $42.1 \mathrm{a}$ & $36.4 \mathrm{~b}$ & $40.0 \mathrm{~b}$ & $39.6 \mathrm{~b}$ & 15.46 \\
Propionate & 11.6 & 12.2 & 12.9 & 11.8 & 13.6 & 12.0 & 3.19 \\
Iso-butyrate & $1.2 \mathrm{bc}$ & $1.1 \mathrm{c}$ & $1.6 \mathrm{a}$ & $1.1 \mathrm{bc}$ & $1.5 \mathrm{ab}$ & $1.3 \mathrm{abc}$ & 0.07 \\
Butyrate & 2.3 & 2.3 & 2.6 & 2.4 & 2.2 & 2.4 & 0.11 \\
Valeric & 0.65 & 0.61 & 0.71 & 0.66 & 0.67 & 0.66 & 0.01 \\
Total & $52.7 \mathrm{~b}$ & $52.3 \mathrm{~b}$ & $59.9 \mathrm{a}$ & $52.3 \mathrm{~b}$ & $58.0 \mathrm{ab}$ & $55.9 \mathrm{~b}$ & 30.6 \\
Acetate propionate ratio & 3.34 & 3.08 & 3.38 & 3.2 & 3.15 & 3.51 & 0.17
\end{tabular}

${ }^{a, b, c}$ Within a row, means with a similar superscript were not detected as being different with probability $P=0.05$

T1: TMR plus hay treated with $0.4 \mathrm{ml} / \mathrm{kg}$ cellulase plus and $0.0 \mathrm{ml} / \mathrm{kg}$ xylanase plus, T2: TMR plus hay treated with 0.3 $\mathrm{ml} / \mathrm{kg}$ cellulase plus and $0.1 \mathrm{ml} / \mathrm{kg}$ xylanase plus, T3: TMR plus hay treated with $0.2 \mathrm{ml} / \mathrm{kg}$ cellulase plus and $0.2 \mathrm{ml} / \mathrm{kg}$ xylanase plus, T4: TMR plus hay treated with $0.1 \mathrm{ml} / \mathrm{kg}$ cellulase plus and $0.3 \mathrm{ml} / \mathrm{kg}$ xylanase plus, T5: TMR plus hay treated with $0.0 \mathrm{ml} / \mathrm{kg}$ cellulase plus, and $0.4 / \mathrm{kg}$ xylanase plus, T6: control without enzyme addition

\section{Conclusion}

Pre-treating Smutsfinger hay with $50-75 \%$ mixture of the cellulase and $50-25 \%$ xylanase led to higher gas production and butyrate concentration, decreased ruminal $\mathrm{pH}$, and improved $\mathrm{DM}$ and fibre degradation. Similarly, during the in vivo study, pre-treatment of Smutsfinger hay with a mixture of $50 \%$ cellulase and xylanase plus enzyme increased that acetate and total VFA concentrations and enhanced the intake and the total tract digestibility of the NDF and ADF components of the feed. This suggests that a $50 \%$ cellulase and xylanase plus enzyme mixture is the optimal concentration that could be used for practical application to improve nutrient digestibility, rumen fermentation parameters and fibre digestion in vivo.

\section{Acknowledgements}

This study was financed partly by IAEA through a grant received by the University of Pretoria as part of research contract number SAF16326. Additional funding was provided by the National Research Foundation, South Africa. The authors are also grateful for the postdoctoral fellowship provided by the Research Office, University of Pretoria, to the third author.

\section{Authors' Contribution}

$\mathrm{KS}$ and $\mathrm{AH}$ designed the study. KS collected data, whereas $\mathrm{KS}$ and $\mathrm{AH}$ were involved in data analysis. KS, AMA and $\mathrm{AH}$ wrote the draft manuscript. AMA, AH and AZMS did the editing and proofreading. AH funded and supervised the study.

\section{Conflict of Interest Declaration}

There are no conflicts of interest.

\section{References}

Akanmu, A.M. \& Hassen, A., 2018. The use of certain medicinal plant extracts reduced in vitro methane while improving in vitro organic matter digestibility. Anim. Prod. Sci. 58(5), 900-908. DOI: 10.1071/AN16291

Allen, M.S., 1996. Physical constraints on voluntary intake of forages by ruminants. J. Anim. Sci. 74, 3063-3075. DOI: 10.2527/1996.74123063x

Allison, C.D., 1985. Factors affecting forage intake by range ruminants: A review. J. Range Management 38(4), 305-311. DOI: $10.2307 / 3899409$

Alvarez, G., Pinos-Rodriguez, J.M., Herrera, J.G., Garcia, J. C., Gonzalez, S.S. \& Barcena, R., 2009. Effects of exogenous fibrolytic enzymes on ruminal digestibility in steers fed high fibre rations. Livest Sci. 121, 150-154. https://doi.org/10.1016/j.livsci.2008.05.024

AOAC, 2019. Official methods of analysis. 21st edition. Rockville, Maryland, USA.

Bala, P., Malik, R. \& Srinivas, B., 2009. Effect of fortifying concentrate supplement with fibrolytic enzymes on nutrient utilization, milk yield and composition in lactating goats. J. Anim. Sci. 80, 265-272. DOI: 10.1111/j.17400929.2009.00634.x

Beauchemin, K.A., Colombatto, D., Morgavi, D.P. \& Yang, W.Z., 2003. Use of exogenous fibrolytic enzymes to improve feed utilization by ruminants. J. Anim. Sci. 81(E. Suppl. 2), E37-E47. https://www.asas.org/docs/jasfiles/2002_jam_symp.pdf?sfvrsn=0

Burroughs, W., Woods, W., Ewing, S.A., Greig, J. \& Theurer, B., 1960. Enzyme additions to fattening cattle rations. J. Anim. Sci. 19, 458-464. https://doi.org/10.2527/jas1960.192458x 
Chen, X.B. \& Gomes, M.J., 1992. Estimation of microbial protein supply to sheep and cattle based on urinary excretion of purine derivatives - an overview of the technical details. International Feed Resources Unit, Rowett Research Institute, Bucksburn, Aberdeen, AB2 9SB, UK. Occasional Publication.

Decruyenaere, V., Buldgen, A. \& Stilmant, D., 2009. Factors affecting intake by grazing ruminants and related quantification methods: A review. Biotechnologie, Agronomie, Société et Environnement 13(4), 559-573.

Elwakeel, E.A., Titgemeyer, E.C., Johnson, B.J., Armendariz, C.K. \& Shirley, J.E., 2007. Fibrolytic enzymes to increase the nutritive value of dairy feedstuffs. J. Dairy Sci. 90, 5226-5236. DOI: 10.3168/jds.2007-0305

Feng, P., Hunt, C.W., Pritchard, G.T. \& Julien, W.E., 1996. Effect of enzyme preparations on in situ and in vitro degradation and in vivo digestive characteristics of mature cool season grass forage in beef steers. J. Anim. Sci. 74, 1349-1357. DOI: 10.2527/1996.7461349x

Fernandes, P., 2018. Enzymatic processing in the food industry. Reference Module in Food Science. https://doi.org/10.1016/B978-0-08-100596-5.22341-X

Fredeen, A.H. \& McQueen, R.E., 1993. Effect of enzyme additives on quality of alfalfa/grass silage and dairy cow performance. Can. J. Anim. Sci. 73, 581-591. DOI:10.4141/CJAS93-062

Gemeda, B.S. \& Hassen, A., 2015. Methane production of two roughage and total mixed ration as influenced by cellulase and xylanase enzyme addition. Sci. Agric. 72(1), 11-19. https://doi.org/10.1590/0103-9016-2014-0155

Gemeda, B.S., Hassen A. \& Odongo, N.E., 2014. Effect of fibrolytic enzyme products at different levels on in vitro ruminal fermentation of low quality feeds and total mixed ration. JAPS 24(5), 1293-1302.

Geraldo, L.A., Tejido, M.L., Ranilla, M.J., Ramos, S. \& Carro, M.D., 2008. Influence of direct-fed fibrolytic enzymes on diet digestibility and ruminal activity in sheep fed a grass hay-based diet. J. Anim. Sci. 86, 1617-1623.

Giraldo, L.A., Tejido, M.L., Ranilla, M.J. \& Carro, M.D., 2008. Effects of exogenous fibrolytic enzymes on in vitro ruminal fermentation of substrates with different forage:concentrate ratios. Anim. Feed Sci. Technol. 141, 306-325. https://doi.org/10.1016/j.anifeedsci.2007.06.013

Hatfield, R.D., Ralph, J. \& Grabber, J.H., 1999. Cell wall structural foundations: Molecular basis for improving forage digestibilities. Crop Sci. 39, 27-37. DOI:10.2135/cropsci1999.0011183X003900010005x

Johnson, T.R. \& Combs, D.K. 1992. Effects of inert rumen bulk on dry matter intake in early and mid-lactation cows fed diets differing in forage content. J. Dairy Sci. 75, 508-519. https://doi.org/10.3168/jds.S0022-0302(92)77788-1

Krueger, N.A., Adesogan, A.T., Staples, C.R., Krueger, W.K., Dean, D.B. \& Littell, R.C., 2008. The potential to increase digestibility of tropical grasses with a fungal, ferulic acid esterase enzyme preparation. Anim. Feed Sci. Technol. 145, 95-108. https://doi.org/10.1016/j.anifeedsci.2007.05.042

Kung, L., Cohen, M.A., Rode, L.M. \& Teacher, R.J., 2002. The effect of fibrolytic enzymes sprayed on to forages fed in total mixed ration to lactating dairy cows. J. Dairy Sci. 85, 2396-2402. https://doi.org/10.3168/jds.S00220302(02)74321-X

Lewis, G.E., Hunt, C.W., Sanchez, W.K., Treacher, R., Pritchard, G.T. \& Feng, P. 1996. Effect of direct-fed fibrolytic enzymes on the digestive characteristics of a forage-based diet fed to beef steers. J. Anim. Sci. 74, 3020-3028. DOI: $10.2527 / 1996.74123020 x$

Meissner, H.H., 1997. Recent research on forage utilization by ruminant livestock in South African Anim. Feed Sci. Technol. 69, 103-119. https://doi.org/10.1016/S0377-8401(97)81626-4

Menke, K. \& Steingass, H., 1988. Estimation of the energetic feed value obtained from chemical analysis and in vitro production using rumen fluid. Anim. Res. Dev. 28:7-55.

Moran, J., 2005. Tropical dairy farming: Feeding management for small holder dairy farmers in the humid tropics. Melbourne: CSIRO, Clayton Victoria, Australia.

Nsereko, V., Morgavi, D.P., Rode, L.M., Beauchemin, K.A. \& McAllister, T.A., 2000. Effects of fungal enzyme preparations on hydrolysis and subsequent degradation of alfalfa hay fibre by mixed rumen microorganisms in vitro. Anim. Feed Sci. Technol. 88, 153-170. https://doi.org/10.1016/S0377-8401(00)00225-X

Rode, L.M., Yang, W.Z. \& Beauchemin, K.A., 1999. Fibrolytic enzymes supplements for dairy cows in early lactation. J. Dairy Sci. 82, 2121-2126.

Rodriguez, J.M.P., Gonzalez, S.S., Mendoza, G.D., Barcena, R., Cobos, M.A., Hernandez, A. \& Ortega, M.E., 2002. Effect of exogenous fibrolytic enzyme on ruminal fermentation and digestibility of alfalfa and rye-grass hay fed to lambs. J. Anim. Sci. 80, 3016-3020. DOI: 10.2527/2002.80113016x

Selig, M.J., Knoshaug, E.P., Adney, W.S., Himmel, M.E. \& Decker, S.R., 2008. Synergistic enhancement of cellobiohydrolase performance on pretreated corn stover by addition of xylanase and esterase activities. Bioresource Technology. 99(11), 4997-5005. https://doi.org/10.1016/j.biortech.2007.09.064

Sutton, J.D., Phipps, R.H., Beever, D.E., Humphries, D.J., Hartnell, G.F., Vicini, J.L. \& Hard, D.L., 2003. Effect of method of application of a fibrolytic enzyme product on digestive processes and milk production in Holstein-Friesian cows. J. Dairy Sci. 86, 546-556. https://doi.org/10.3168/jds.S0022-0302(03)73633-9

Theurer, B., Woods, W. \& Burroughs, W., 1963. Influence of enzyme supplements in lamb fattening rations. J. Anim. Sci. 22, 150-154. https://doi.org/10.2527/jas1963.221150x

Wang, Y., McAllister, T.A., Rode, L.M., Beauchemin, K.A., Morgavi, D.P., Nsereko, V.L., Iwassa, A.D. \& Yang, Z.W., 2001. Effects of an exogenous enzyme preparation on microbial protein synthesis, enzyme activity and attachment to feed in the rumen simulation technique. Br. J. Nutr. 85, 325-332. DOI: 10.1079/bjn2000277

Webb, E.C., Bosman, M.J.C., Casey, N.H., 1994. Dietary influences on subcutaneous fatty acid profiles and sensory characteristics of Dorper and SA Mutton Merino wethers. S. Afr. J. Food Sci. Nutr. 6, 45-50.

Yang, W.Z., Beauchemin, K.A. \& Vedres, D.D., 2002. Effects of $\mathrm{pH}$ and fibrolytic enzymes on digestibility, bacterial protein synthesis, and fermentation in continuous culture. Anim. Feed Sci. Technol. 102(1), 137-150. https://doi.org/10.1016/S0377-8401(02)00250-X 